\title{
Urine Calcitonin in Normal Children
}

\author{
O. L. SILVA, ${ }^{(15)}$ K. L. BECKER, R. H. SNIDER, C. F. MOORE, AND H. M. LANDO \\ Metabolic Research Laboratory, Veterans Administration Medical Center, the Department of Oncology, Howard \\ University, and the Department of Medicine, George Washington University, Washington, D. C., USA
}

\begin{abstract}
Summary
Although it is known that calcitonin decreases bone resorption, lowers serum calcium and phosphate, and influences the urinary excretion of these ions, its effect upon skeletal maturation in growing children has not been elucidated. Conceivably, the higher serum calcitonin levels that have been reported in children may promote bone formation and growth.

To study immunoreactive urine calcitonin (iCT) in normal children, we used the radioimmunoassay (RIA) which we had developed previously to measure the hormone in normal adults and to screen persons at risk for medullary thyroid carcinoma (MTC). The measurement of urine iCT by RIA is particularly useful for children at risk for this thyroid malignancy because it obviates the need for venipunctures. Two antisera, one having region specificity for the midportion of CT (Ab-IIIb) and the other having carboxyl terminal recognition (Ab-IV), were utilized for the assay.

For the carboxylterminal antiserum (Ab-IV), boys of ages 7 to 12 years (mean urine $\mathrm{iCT},(\mathrm{ng} / \mathrm{mg} \pm$ S.D.), $0.29 \pm 0.18$ ) had urine iCT levels significantly higher than girls the same age $(0.13 \pm$ $0.05)$ and higher than both adult males $(0.16 \pm 0.07)$ and adult females $(0.084 \pm 0.034)$. Boys ages 13 to 15 years $(0.12 \pm 0.03)$ had urine iCT concentrations which were not different from adult males. Girls of ages 7 to 12 years $(0.13 \pm 0.05)$ had iCT levels significantly lower than boys of the same age $(0.29 \pm 0.18)$, but significantly higher than adult females $(0.084 \pm 0.034)$. Girls ages 13 to $15(0.11 \pm 0.05)$ had urine iCT levels not significantly different from boys of the same age $(0.12 \pm 0.03)$.
\end{abstract}

For the midportion antiserum (Ab-IIIb), children ages 7 to 15 $(0.58 \pm 0.384)$ had urine iCT concentrations greater than adults $(0.26 \pm 0.10)$, but there were not significant differences in levels between boys and girls of the same age.

Gel filtration studies revealed greater amounts of higher molecular weight fractions ( $\mathrm{pU}-2, \sim 14,600$ daltons; $\mathrm{pU}-3, \sim 11,000)$ of urine calcitonin than were found in the urine of most normal adults and all patients with MTC.

Previously, we have established criteria for diagnosing MTC in adults using Ab-IV in the urine calcitonin RIA. These adult criteria can be applied to females of all ages and to males $\geq 12$ years of age, but levels for boys $<12$ years require the adjusted criteria reported in this publication. In the present study, when using $A b$ IV (the carboxyl terminal antiserum used in the previous MTC study), we have found higher urine iCT levels in children than among adults. The mean level in the various age groups decreased with age. Using the data obtained from this study, we can be more certain of our determination that a child between the ages of 6 and 15 is either normal or has MTC.

\section{Speculation}

Urine immunoreactive calcitonin (iCT) measured by radioimmunoassay has been found to be a very sensitive indication of the presence of medullary thyroid carcinoma in patients at risk for the familial form of the disease. Using two region specific antisera, we have determined iCT levels in the urine of normal children to provide an age- and sex-matched control group for children being screened for this thyroid malignancy. Urine $\mathrm{ICT}$ is higher in children and tends to decrease at puberty. Interesting differences are observed in the recognition of urine iCT by two different antisera in terms of sex and age. Do these observations have important physiologic relevance in regard to bone formation and growth?

Although it is known that calcitonin decreases bone resorption, lowers serum calcium and phosphate, and influences the urinary excretion of these ions, its effect upon skeletal maturation in growing children has not been elucidated. In this regard, serum levels of immunoreactive calcitonin (iCT) have been reported to be higher in newborns and children than in adults (8). Conceivably, higher iCT levels in children may promote bone formation and growth. Whether this high iCT of newborns is transient has not been determined nor has the age at which children attain adult levels of the hormone been defined.

When we screened persons at risk for MTC using the RIA which we have developed for urine iCT, we found the measurement of the hormone in urine to be a more sensitive indication of the presence of this thyroid malignancy than that in the serum $(10,11)$. In our studies of serum and urine iCT in normal adults and in children and adults with MTC, we found that increased urinary iCT reflected increased secretion of the hormone and was always accompanied by either a high basal level and/or a high stimulated level of serum iCT. The measurement of urine iCT is particularly useful for children at risk for MTC because it obviates the need for venipuncture. Accordingly, to facilitate the screening of children for this neoplasm, we have determined concentrations of urine $\mathrm{iCT}$ in normal children.

\section{MATERIALS AND METHODS}

The RIA of urine iCT has been described previously (11). Second morning specimens of urine are collected in polyethylene receptacles containing sufficient $\mathrm{NH}_{4} \mathrm{HCO}_{3}$ to maintain a $\mathrm{pH}$ $\geq 7.5$. First morning urine specimens are not used because some iCT can be degraded in the acid media of the bladder. After boiling to denature enzymes which may degrade $\mathrm{iCT}$ (present in significant amounts in $<5 \%$ of urines), the urine samples are chromatographed on $5 \mathrm{ml}$ Bio-Gel P-2 columns (containing $0.1 \mathrm{M}$ $\mathrm{NH}_{4} \mathrm{HCO}_{3}$ buffer at $\mathrm{pH} 7.5$ ) to remove interfering salts and purines.

Two antisera, one having region specificity for the midportion of calcitonin (Ab-IIIb) and the other having carboxyl terminal recognition (Ab-IV) were utilized for the measurement of urine $\mathrm{iCT}$. Urine $\mathrm{iCT}$ is expressed as $\mathrm{ng} \mathrm{iCT}$ per $\mathrm{mg}$ creatinine to eliminate the necessity for collecting urine during a timed period. Gel filtration studies were done using G-75 superfine Sephadex $(3 \times 110 \mathrm{~cm}$ columns, $\mathrm{pH} 7.5)$ as we have previously described (12). Urines containing $<0.5 \mathrm{ng} / \mathrm{ml}$ of $\mathrm{iCT}$ were concentrated before gel filtration. Urine (100 to $200 \mathrm{ml}$ ) was boiled, flash evaporated, and lyophilized. The dried material was extracted with three $10 \mathrm{ml}$ aliquots of $1 \mathrm{~N} \mathrm{NH}_{4} \mathrm{OH}$ :acetonitrile $(1: 1)$, and the extract was lyophilized (1). This lyophilisate was reconstituted in $10 \mathrm{ml}$ of $0.1 \mathrm{M} \mathrm{NH}_{4} \mathrm{HCO}_{3}$ at $\mathrm{pH} 7.5$ for column chromatography and subsequent RIA. To establish levels of urine iCT for normal 
children, we have studied urine from 60 boys and girls in a grammar school and 13 children in nursery schools. Appropriate consent forms were obtained.

\section{RESULTS}

The means \pm S.D. of urine iCT for children are tabulated by age categories along with the $P$ value for comparison between the levels of urine iCT of children of various ages and sexes (Table 1).

For the carboxyl terminal antiserum (Ab-IV), boys ages 7 to 12 years had urine iCT levels significantly higher than girls the same age and significantly higher than both adult males and adult females. Boys ages 13 to 15 years had urine iCT concentrations similar to those of adult males. Girls ages 6 to 12 years had iCT levels significantly lower than boys of the same age, but significantly higher than adult females. Girls ages 13 to 15 had urine iCT levels not significantly different from boys of the same age.

For the midportion antiserum (Ab-IIIb), children of ages 6 to 15 had urine iCT concentrations significantly greater than adults, but there were no significant differences in levels between boys and girls of the same ages.

Gel filtration revealed a greater concentration of higher molecular weight fractions of urine iCT (pU-2, 14,600; pU-3, 11,000), than were found in the urine of most normal adults and patients with MTC (Figs. 1 and 2). Ab-IIIb binds these high-molecularweight fractions with greater avidity than Ab-IV. Interestingly, extracted cardiac blood obtained at autopsy had an iCT fraction of the same molecular size as pU-3 (Fig. 2), and previously, we reported serum iCT fraction IIA corresponding in molecular size to $\mathrm{pU}-2$.

Previously, we have established criteria for the diagnosis of MTC in adults with the urine calcitonin RIA using Ab-IV (10). The aforementioned adult criteria can be applied to females of all ages and to males $>12$ years, but criteria for boys $\leq 12$ years requires the adjusted criteria indicated in Table 1. Another observation which may prove clinically useful in the diagnosis of MTC for children $<15$ years old is the ratio of iCT as measured by midportion antiserum, Ab-IIIb, to the $\mathrm{iCT}$ as measured by carboxyl terminal antiserum, Ab-IV. The Ab-IIIb:Ab-IV ratio was
$<1.0$ for 21 of $21(100 \%)$ MTC patients and $>1.0$ for 75 of 76 $(98 \%)$ normal children $<15$ years old.

\section{DISCUSSION}

It is known that normal newborns have high serum levels of iCT (8). In a study of normal children, 24\% of those aged 5 to 10 years had serum iCT levels higher than adults (7). In 1973, Wolfe et al. (13) described C cell hyperplasia in children of families with type II multiple endocrine neoplasia and showed that $\mathrm{C}$ cell hyperplasia is a precursor of MTC in these families. Later, the same group reported their experiences performing total thyroidectomies on this subset of patients (4). In all cases but one, neck exploration confirmed the diagnosis. Neck exploration was performed in only one child in whom $\mathrm{C}$ cell hyperplasia was not encountered, although their usual protocol of stimulatory tests had suggested the presence of either MTC or C cell hyperplasia. Because many of the patients at risk for MTC are children and because these children might have to be screened at yearly intervals, it is important to discriminate between normal children and those with $\mathrm{C}$ cell hyperplasia who may be destined to develop MTC. In our previous study of patients with MTC, we were able to diagnose correctly $75 \%$ of those screened by using the urine iCT RIA without the need for blood samples or stimulation tests.

In most laboratories, neither normal control levels nor stimulatory levels of serum iCT have been determined in children of various ages. Carey et al. (2) reported basal studies for five normal children in whom calcium and pentagastrin infusions were also done. In that study, no differences from adults were observed in basal levels of serum iCT; however, calcium-stimulated serum iCT levels were higher in children than in adults. David et al. (3) found serum iCT to be undetectable $(<150 \mathrm{pg} / \mathrm{ml})$ in four of 15 newborns of low and normal birth weight, up to $2 \mathrm{hr}$ after birth. In this latter study, a marked increase in iCT occurred at 12 to $14 \mathrm{hr}$ and again at 22 to $26 \mathrm{hr}$ followed by a decrease at 44 to $48 \mathrm{hr}$; serum iCT correlated negatively with gestational age.

Shainkin-Kerstenbaum et al. (9) studied 37 normal children between ages of 6 to 12 and found a significant rise in serum iCT levels with age. These concentrations, which were frequently

Table 1. Urine iCT of children and adults $(>22 \text { years of age })^{1}$

\begin{tabular}{|c|c|c|c|c|c|c|c|c|c|c|}
\hline & \multicolumn{2}{|c|}{$\leq 6 \mathrm{yrs}$} & \multicolumn{2}{|c|}{$7-12$ yrs } & \multicolumn{2}{|c|}{$13-15$ yrs } & \multicolumn{2}{|c|}{$18-22 \mathrm{yrs}$} & \multicolumn{2}{|c|}{$\geq 23$ yrs } \\
\hline & Ab-IV & $\mathrm{Ab}-\mathrm{IIIb}$ & Ab-IV & Ab-IIIb & Ab-IV & Ab-IIIb & Ab-IV & Ab-IIIb & Ab-IV & Ab-IIIb \\
\hline Females & $0.31 \pm 0.24^{2}$ & $0.62 \pm 0.23$ & $0.13 \pm 0.05$ & $0.47 \pm 0.18$ & $0.11 \pm 0.05$ & $0.42 \pm 0.19$ & & & $0.084 \pm 0.034$ & $0.27 \pm 0.13$ \\
\hline Males & $0.41 \pm 0.17$ & $0.70 \pm 0.27$ & $0.29 \pm 0.18$ & $0.65 \pm 0.46$ & $0.12 \pm 0.03$ & $0.41 \pm 0.08$ & $0.16 \pm 0.08$ & $0.23 \pm 0.07$ & $0.16 \pm 0.07$ & $0.25 \pm 0.06$ \\
\hline $\begin{array}{l}P \text { for difference } \\
\text { (males vs. fe- } \\
\text { males) }\end{array}$ & N.S. & N.S. & $<0.01$ & N.S. & N.S. & N.S. & & & $<0.001$ & N.S. \\
\hline $\begin{array}{l}\text { Females < } 6 \text { yrs } v s \text {. } \\
\text { females }\end{array}$ & & & N.S. & $<0.05$ & N.S. & $<0.05$ & & & $<0.02$ & $<0.001$ \\
\hline $\begin{array}{l}\text { Females } 7-12 \text { yrs } \\
\text { vs. females }\end{array}$ & $<0.03$ & N.S. & & & N.S. & N.S. & & & $<0.01$ & $<0.002$ \\
\hline $\begin{array}{c}\text { Females } 13-15 \text { yrs } \\
\text { vs. females }\end{array}$ & $<0.04$ & N.S. & N.S. & N.S. & & & & & N.S. & $<0.03$ \\
\hline $\begin{array}{l}\text { Females } \geqslant 23 \text { yrs vs. } \\
\quad \text { females }\end{array}$ & $<0.002$ & $<0.001$ & $<0.01$ & $<0.002$ & N.S. & $<0.03$ & & & & \\
\hline $\begin{array}{l}\text { Males } \leq 6 \text { yrs } v s . \\
\text { males }\end{array}$ & & & N.S. & N.S. & $<0.001$ & N.S. & $<0.001$ & $<0.001$ & $<0.001$ & $<0.001$ \\
\hline $\begin{array}{l}\text { Males } 7-12 \text { yrs vs. } \\
\text { males }\end{array}$ & N.S. & N.S. & & & $<0.01$ & N.S. & $<0.003$ & $<0.001$ & $<0.003$ & $<0.001$ \\
\hline $\begin{array}{l}\text { Males } 13-15 \text { yrs } v s . \\
\text { males }\end{array}$ & $<0.001$ & $<0.01$ & $<0.01$ & N.S. & & & N.S. & $<0.001$ & N.S. & $<0.001$ \\
\hline $\begin{array}{l}\text { Males } 18-22 \text { yrs. } v s . \\
\text { males }\end{array}$ & $<0.001$ & $<0.001$ & $<0.003$ & $<0.001$ & N.S. & $<0.001$ & & & N.S. & N.S. \\
\hline $\begin{array}{l}\text { Males } \geqslant 23 \text { yrs } v s \\
\text { males }\end{array}$ & $<0.001$ & $<0.001$ & $<0.003$ & $<0.001$ & N.S. & $<0.001$ & N.S. & N.S. & & \\
\hline
\end{tabular}

\footnotetext{
${ }^{1} \mathrm{ng}$ iCT/mg creatinine.
}

${ }^{2}$ Mean \pm S.D. 


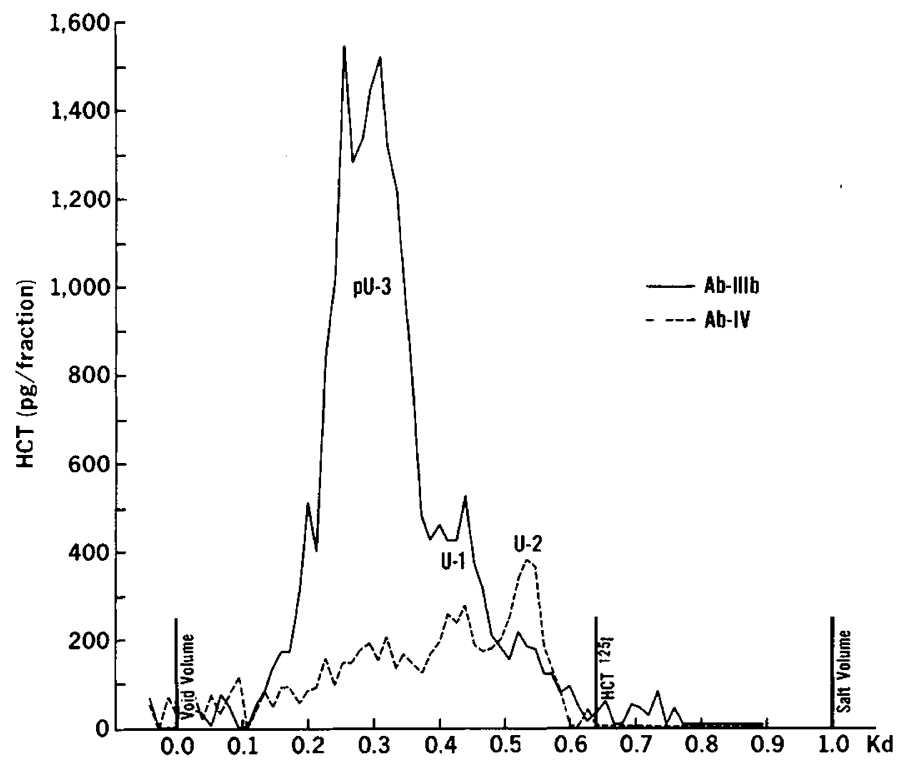

Fig. 1. Gel filtration pattern of urine iCT of a male $<12$ years. old. (Gel filtration studies are carried out at $4^{\circ} \mathrm{C}$ on G-75 superfine Sephadex (Pharmacia Fine Chemicals, Inc., Piscataway, NJ) suspended in a buffer containing per liter, $7.91 \mathrm{~g} \mathrm{NH}_{4} \mathrm{HCO}_{3}$ and $2 \mathrm{~g}$ human serum albumin at a $\mathrm{pH}$ of 7.5 packed into glass columns to a gel volume of $3 \times 110 \mathrm{~cm}$ ).

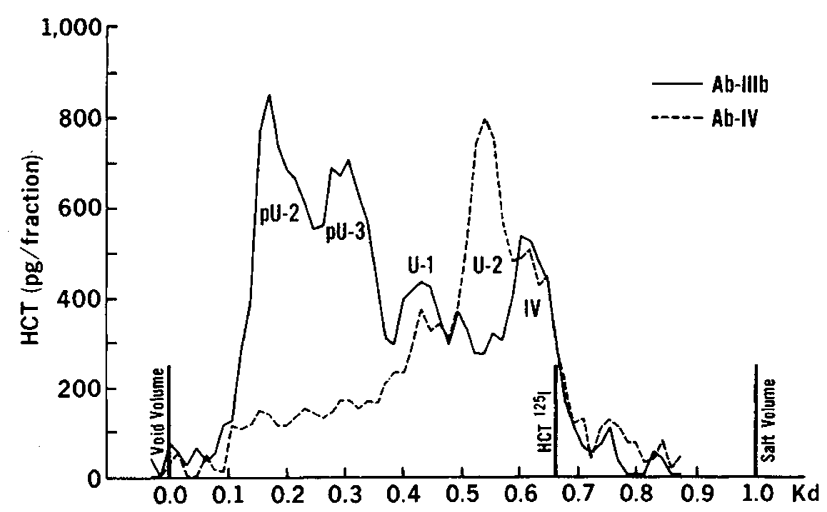

Fig. 2. Gel filtration pattern of urine iCT of a 19-year-old male.

above adult levels, correlated inversely with levels of serum immunoreactive parathyroid hormone and serum phosphate. However, the mean basal serum iCT level of the entire group of children was not significantly different from adults.

Thus, in some of the aforementioned studies, mean serum iCT levels in children were found to be the same as that of adults (2, 9) and in others levels were higher than adults $(3,7,8,11)$. The difficulty in obtaining a control population of normal children and the understandable reluctance of Human Studies Committees to grant permission to collect blood from normal children have both contributed to the paucity of serum data for this age group. To overcome these problems and to provide a better control population for our investigations of the clinical utility of urine iCT, we determined urine iCT concentrations for normal children.

In the present study when using Ab-IV (the carboxyl terminal antiserum which had been used in the previous MTC study) (10) and Ab-IIIb (a midportion antiserum), we have found higher urine iCT levels in children than among adults. The mean levels in the various age groups decreased with age (Table 1). Using the data obtained from this study, we can be more certain whether a child between the ages of 6 and 15 is normal or has MTC.

Although these studies in children have extended the usefulness of our urine test for MTC, they have raised several new questions which require further investigation. Figure 1 shows the gel filtration pattern for the urine of a male child $<12$ years of age, and

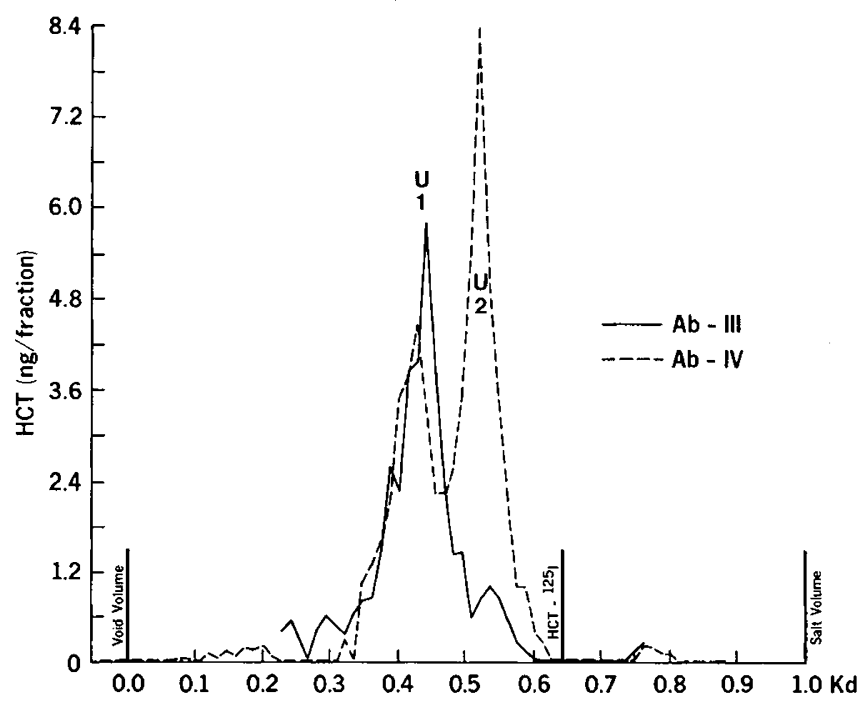

Fig. 3. Gel filtration pattern of urine $\mathrm{iCT}$ of an adult male.

Figure 2 shows the pattern of a 19-year-old male. These patterns are strikingly dissimilar to that found for most adult males ( $>22$ years of age), whose urines usually contain little or no iCT eluting with the same $K_{d}$ as the principal iCT fraction in the child's urine (pU-3) (Fig. 3). It would appear that this high-molecular-weight iCT in the urine of children accounts for the very high levels of iCT as determined with our midportion antiserum, Ab-IIIb.

When studying serum iCT, some laboratories find differences in iCT concentrations according to sex, and others do not $(5,6)$. In view of this controversy over sex-related differences in serum iCT, we would like to emphasize the striking discrepancies between the results obtained for our two antisera with differing region specificities. At no age were we able to find a significant difference between females and males with respect to urine $\mathrm{iCT}$ as quantitated with midportion antiserum, Ab-IIIb. However, as reported by us previously, our carboxyl terminal antiserum, AbIV, quantitates more urine iCT in the urine of adult males than for adult females. Furthermore, in this study, male children $<12$ years also had higher levels of Ab-IV quantitated iCT than did female children $<12$ years. Urine iCT levels of boys and girls of ages 13 to 15 are indistinguishable using Ab-IV. Of considerable interest and possible physiologic significance is the striking decrease in urine $\mathrm{iCT}$ (as quantitated by Ab-IV) at puberty for male children, and the equally striking decrease in urine iCT (as quantitated by $\mathrm{Ab}$-IIIb) observed for all children between ages 15 and 18. Does this marked decline in urine iCT reflect a decrease in C-cell function attendant with the end of the pubertal growth spurt and the concomitant accumulation of bone mass? Are the higher urine iCT levels observed in boys correlated with the higher bone mass eventually attained by males? Additional studies are required to further elucidate the mechanisms and significance of these interesting changes.

\section{REFERENCES AND NOTES}

1. Becker, K. L., Snider, R. H., Moore, C. F., Monaghan, K. G., and Silva, O. L.: Calcitonin in extrathyroidal tissues of man. Acta Endocrinol., 92: 746 (1979).

2. Carey, D. F., Jones, K. L., Parthemore, J. G., and Deftos, L. J.: Calcitonin secretion in congenital nongoitrous cretinism. J. Clin. Invest., 65: 892 (1980).

3. David, L., Chopard, S. P., and Grafmeyer, D.: Studies on circulating immunoreactive calcitonin in low birth weight infants during the first 48 hours of life. Helv. Paediatr. Acta, 32: 39 (1977).

4. Graze, K., Spiler, I. J., Tashjian, A. H., Jr., Melvin, K. E. W., Cervi-Skinner, S., Gagel, R. F., Miller, H. H., Wolfe, H. J., DeLellis, R. A., Leape, L., Feldman, Z. T., and Reichlin, S.: Natural history of familial medullary thyroid carcinoma. N. Engl. J. Med., 299: 980 (1978).

5. Hillyard, C. J., Stevenson, J. C., and MacIntyre, I.: Relative deficiency of plasmacalcitonin in normal women. Lancet, $1: 961$ (1978).

6. Mulder, H., Hacheng, W. H. L., and Silberbusch, J.: Racial differences in serum calcitonin. Lancet, 1: 154 (1979).

7. Samaan, N. A., Anderson, G. D., and Adams-Mayne, M. E.: Immunoreactive 
calcitonin in the mother, neonate, child and adult. Am. J. Obstet. Gynecol., 121: $622 \mathrm{M}(1975)$

8. Samaan, N. A., Hill, C. S., Jr. Beceiro, J. R., and Schultz, P. N.: Immunoreactive calcitonin in medullary carcinoma of the thyroid and in maternal and cord serum. J. Lab. Clin. Med., 81: 673 (1973).

9. Shainkin-Kerstenbaum, R., Funkerstein, B., Conforti, A., Shani, S., and Berlyne, G. M.: Serum calcitonin and blood mineral interrelationships in normal children aged six to twelve years. Pediatr. Res., 11 : 112 (1977).

10. Silva, O. L., Snider, R. H., Moore, C. F., and Becker, K. L.: Urine calcitonin as a test for medullary thyroid cancer: a new screening procedure. Ann. Surg., 189: 269 (1979).

11. Snider, R. H., Moore, C. F., Silva, O. L., and Becker, K. L.: Radioimmunoassay of calcitonin in human urine. Anal. Chem., 50: 449 (1978).

12. Snider, R. H., Silva, O. L., Moore, C. F., and Becker, K. L.: Immunochemical heterogeneity of calcitonin in man: effect on radioimmunoassay. Clin. Chim. Acta, 76: 1 (1977)
13. Wolfe, H. J., Melvin, K. E. W., Cervi-Skinner, S. J., Al Saadi, A. A., Juliar, J. F., Jackson, C. E., and Tashjian, A. H.: C-cell hyperplasia proceeding medullary thyroid carcinoma. N. Engl. J. Med., 289: 437 (1973).

14. The authors are indebted to Christine Mayer, Director of River Park Nursery School; Sister Alice Kelley, Principal of the Saint Anthony's Grade School, and the following teachers: Sister Mary Dorothy, Wayne Straight, Sister Ann Marie, John D'Eufemia, Lorna Holloway, Elizabeth Cunningham, Joan O'Connell, and Diane Wells; Connie Pearson, President of the Tauxamont Cooperative Pre-School; and the parents and the children who participated in the study.

15. Requests for reprints should be addressed to: Omega L. Silva, M. D., Veterans Administration Medical Center, Metabolic Research (151J), 50 Irving St. N.W., Washington, D. C. 20422 (USA).

16. This research was supported VA Medical Research Funds.

17. Received for publication July 22, 1980.

18. Accepted for publication October 6, 1980. 